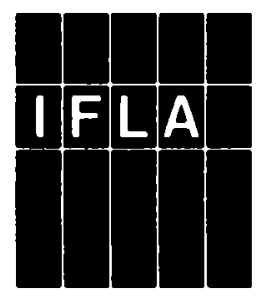


International Federation of Library Associations and Institutions Fédération Internationale des Associations de Bibliothécaires et des Bibliothèques Internationaler Verband der bibliothekarischen Vereine und Institutionen Международная Федерация Библиотечных Ассоциация и Учреждения Federación Internacional de Asociaciones de Bibliotecarios y Bibliotecas

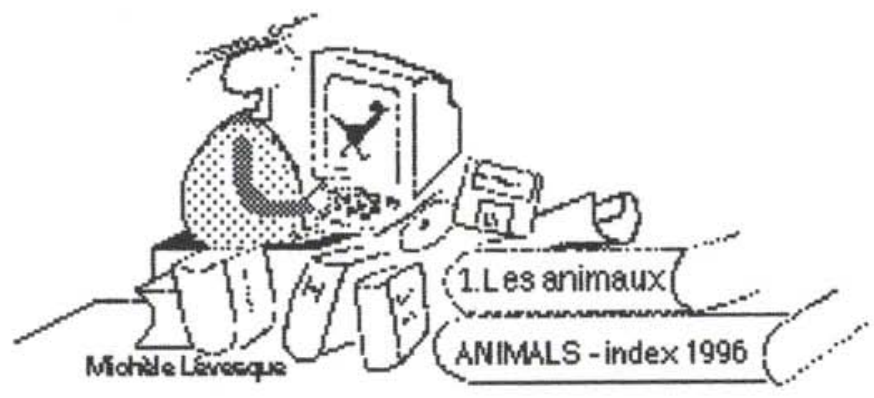

Dans ce document, le genre masculin est utilisé sans discrimination et dans le seul but d'alléger la lecture 
IFLA Publications 79

Section des bibliothèques et centres documentaires scolaires

Section of School Libraries and Resource Centres

\section{Ressources pour les bibliothèques et centres documentaires scolaires}

\section{Resourcebook for School Libraries and Resource Centers}

Edité par / Edited by

Paulette Bernhard

Avec la participation de: / With the participation of:

Colette Charrier, Mary Collis, Margarethe Dahlström, Lucie David, Lin Forrest, Anne M. Galler, Lyn Hay, Teruyo Horikawa, Niels Jacobsen, Torny Kjekstad, Benoit Létourneau, Inci Önal, Richard Morin, Alexandra Papazoglou, Robert Roy, Ramon Salaberria, Marguerite Tremblay, Margaret Tye, Guylaine Vinet, Glenys Willars, Blanche Woolls

K·G· Saur München 1997 
IFLA Publications

edited by Carol Henry

Recommended catalogue entry:

Ressources pour les bibliothèques et centres documentaires

scolaires = Resourcebook for school libraries and resource centers /

Section des Bibliothèques et Centres Documentaires Scolaires.

[International Federation of Library Associations and Institutions].

Ed. par: Paulette Bernhard.

...- München : Saur, 1997, p. VIII, 148, $21 \mathrm{~cm}$

(IFLA publications ; 79)

ISBN 3-598-21805-2

Die Deutsche Bibliothek - CIP-Einheitsaufnahme

Ressources pour les bibliothèques et centres documentaires

scolaires $=$ Resourcebook for school libraries and resource centers /

Section des Bibliothèques et Centres Documentaires Scolaires.

[International Federation of Library Associations and Institutions].

Ed. par: Paulette Bernhard.

...-München : Saur, 1997

(IFLA publications ; 79)

ISBN 3-598-21805-2

Printed on acid-free paper

The paper used in this publication meets the minimum requirements of American National Standard for Information Sciences - Permanence of Paper for Printed Library Materials, ANSI Z39.48.1984.

(C) 1997 by International Federation of Library Associations and Institutions, The Hague, The Netherlands

Alle Rechte vorbehalten / All Rights Strictly Reserved

K. G. Saur Verlag GmbH \& Co. KG, München 1997

Part of Reed Elsevier

Printed in the Federal Republic of Germany

All rights reserved. No part of this publication may be reproduced, stored in a retrieval system of any nature, or transmitted, in any form or by any means, electronic, mechanical, photocopying, recording or otherwise, without the prior written permission of the publisher.

Printed/Bound by Strauss Offsetdruck GmbH, Mörlenbach

ISBN 3-598-21805-2

ISSN 0344-6891 (IFLA Publications) 


\title{
REMERCIEMENTS / ACKNOWLEDGEMENTS
}

Nous tenons à remercier les personnes suivantes

qui ont participé à la production de cet ouvrage :

We would like to thank the following persons who have participated in the making of this book :

\author{
Colette Charrier \\ Mary Collis \\ Margarethe Dahlström \\ Lucie David \\ Lin Forrest \\ Anne M. Galler \\ Lyn Hay \\ Teruyo Horikawa \\ Niels Jacobsen \\ Torny Kjekstad \\ Benoit Létourneau \\ Inci Önal, \\ Richard Morin \\ Alexandra Papazoglou \\ Robert Roy \\ Ramon Salaberria \\ Marguerite Tremblay \\ Margaret Tye \\ Guylaine Vinet \\ Glenys Willars \\ Blanche Woolls
}

et / and : Peter M. Brown for his overall help and patience 